\title{
The Effect of Static Balance Exercises on Reaction Time in Sedentary Female Students
}

\author{
Hakan Acar ${ }^{1}$, Ayça Genç ${ }^{2}$ \\ ${ }^{1}$ Department of Physical Education and Sport, Zonguldak Bülent Ecevit University, Zonguldak, Turkey \\ ${ }^{2}$ Department of Physical Education and Sport, Muş Alparslan University, Muş, Turkey \\ Correspondence: Ayça Genç Department of Physical Education and Sport, Muş Alparslan University, Muş, Turkey.
}

Received: February 11, 2019

Accepted: March 13, $2019 \quad$ Online Published: March 19, 2019

doi:10.11114/jets.v7i4.4038

URL: https://doi.org/10.11114/jets.v7i4.4038

\begin{abstract}
The purpose of this study is to analyze the effect of 8 week static balance exercises on reaction time. 38 sedentary female students voluntarily participated in the study. The volunteers were selected randomly and were separated into 2 groups as the experiment group $(n=19)$ and the control group $(n=19)$. While the experiment group participated in static balance exercises in their physical education lessons for 8 weeks, the control group only participated in the physical education lessons. The visual and auditory reaction times of the samples were carried out with the Newtest 1000 device as pre-test and post-test. The data were evaluated with the SPSS 20.0 statistical software program and since there was no normal distribution, the wilcoxon signed rank test which is one of the non-parametrical tests was carried out and the significance level was determined as $\mathrm{p}<0.05$. The age average of the volunteers $(n=38)$, was determined as $15.8 \pm 1,50$ years, height averages as $160,3 \pm 5,48 \mathrm{~cm}$ and body weight averages as $53,33 \pm 7,50 \mathrm{~kg}$. As a result of the statistical analysis, it was found that there was no significant differences in either of the groups between the pre-rest and post-test visual and auditory reactions ( $p>0.05$ ). As a result, it was determined that 8 week balance tests did not affect the visual and auditory reaction times of the female students.
\end{abstract}

Keywords: reaction time, balance, physical education lesson

\section{Introduction}

Individuals' reaction times occur through the central nervous system and muscles as a result of the interaction between appropriate components and various factors (Eren et al., 2017). In physiological terms, reaction time takes place as a result of five stages as a stimulant taking place in the receptor level, spreading of the stimulant to the central nervous system, production of the effector signal through the stimulant's being carried by neurological paths, the signal's being carried from the central nervous system to the muscles and the contraction of the muscles to produce mechanical activity as a result of the stimulus (Bompa 1990). Reaction time is defined as the time between giving the stimulus to the individual and the individual's voluntary reaction to the stimulus (Açıada, 1990; Çankaya, 2014). Reaction time changes from person to person and situation to situation. In general, the reaction time being long is an indication that the individual gives less attention to the stimulant (Fox et al., 1999).

Reaction time is extremely important in our daily lives. The measurements obtained from the simple reaction time tests give information about a person's neurological and cognitive functionality in a given activity (Okkesim and Coşkun 2015). Reaction time is an important criterion in sports due to being a part of sportive components which include muscle-nerve performance and hand-eye coordination and it has been determined that reaction time can be developed through regular exercise (Çolakoğlu et al., 1993).

Sports being done regularly improves the development of circulatory, respiratory and muscle systems in adolescent individuals and increases physical capacity. While exercises done at early ages provide protection against various diseases such as cancer, diabetes, obesity and cardiovascular diseases, they also help to develop motor characteristics. A positive development takes place in the perception and reaction times of adolescents who exercise (Sevim, 2002). Therefore, it is important that the balance skill of individuals (Aksu, 1994) which is defined as a determinant factor in the development of other motor systems to be studied together with its relation to reaction time.

Balance is the foundation of all movements (Brown and Ferrigno, 2005). Balance is needed to protect the body position 
during a movement, speeding up and slowing down and during sudden place and direction changes. Balance is necessary in the performance of a number of motor duties (Malina, 1999). Balance is separated into two as static balance and dynamic balance. Static balance is the skill of keeping the body's balance in a certain place or position, whereas dynamic balance is the skill of keeping the body's balance while moving (Muratl 1997, Hazar and Taşmektepligil 2008).

Balance starts developing in the pre-school period and reaches its top level at age 17-18 in girls and decreases as they get older (Muratl1, 2003). Our study was planned to analyze the effects of 8 week static balance exercises on the reaction time of girls who are at their top level in terms of balance development.

\section{Method}

38 sedentary female students with an age average of $15.8 \pm 1,50$ who are receiving education at the İstanbul Stock Exchange Vocational and Technical Anatolian high-school in Osmangazi, Bursa volunteered to participate in our study. The students were chosen randomly and separated into two groups as the experiment $(n=19)$ and control group $(n=19)$. While the experiment group participated in static balance exercises in their physical education lessons for 8 weeks, the control group only participated in the physical education lessons. The volunteers' height, weight and visual and auditory reaction times were measured. They were warned about not taking any stimulant medicine, not consuming caffeine and not doing any exhausting activities prior to 24 hours of measuring the reaction times.

After the volunteers were informed about the content, purpose and application of the study, their consent about volunteering to participate in the study and the other required approvals were taken. It was determined that there were no students among the volunteers who had visual and auditory handicaps and that they did not have any other handicaps which were formed in the recent times or have had a surgery which could influence the measurements.

\subsection{Measures}

The body weights of the students were measured with an electronical scale with a sensitivity of $0.1 \mathrm{~kg}$ and their heights were measured with a digital stadiometer with a sensitivity of $0.01 \mathrm{~cm}$.

\subsubsection{Reaction Time Measurement}

The visual and auditory reaction time measurements were carried out with the Newtest 1000 device. In the application part of the study, the participants were lined side by side and asked to put their palms on a table with their fingers in the closed position. They were asked to leave a fixed distance of $30 \mathrm{~cm}$ between the table and themselves. Their hands were placed $10 \mathrm{~cm}$. in front of the Newtest device's reaction indicators and they were asked not to move their other hand. They were given 3 light and 3 sound signals for the measurement of the reaction to sound of the right hand, reaction to sound of the left hand, reaction to light of the right hand and reaction to light of the left hand and the best reaction time values were recorded by the researcher on the form developed by her in milliseconds.

\subsection{The Static Balance Exercise Program}

The static balance exercise group $(n=19)$ was given a static balance exercise program for 8 weeks in their physical education lessons, which consisted of 2 sets of 10 movements for each session; these movements were required to be performed with eyes open for the first four weeks and eyes closed in the second four weeks and the movements' duration started with 5 second and reached 12 seconds at the end of 8 weeks. The increase in load was achieved through the increase in the duration of the movements and the change in the muscle groups involved in the movements. The principle of full rest was applied between the movements and the rest time between the sets was determined as 1 minute.

Static Balance Exercises: Standing on one leg (right, left), tree position (right, left), standing on one leg in the relief position (right, left), raising the leg 90 degrees to the front in the standing straight position (right, left), sailplane position (right, left), side balance (right, left), bending forwards with one leg on top of the other leg (right, left), forward movement (right, left), side movement (right, left), backward movement (right, left) (Erdoğan et al., 2017).

\subsection{Analysis of Data}

The data were analyzed with the SPSS 20.0 statistical software program. Since the distribution of the data was not normal, the Wilcoxon Signed rank test which is one of the non-parametrical tests was done the statistical significance level was determined as $\mathrm{p}<0.05$. 


\section{Results}

In the study in which the reaction times of the experiment group and the control group were determined, the findings are presented in the tables below.

Table 1. Comparison of the Experiment Group's Visual Reaction Pre-test and Post-test Values

\begin{tabular}{|c|c|c|c|c|c|}
\hline Right Hand & $\mathrm{n}$ & Mean Rank & Sum of Ranks & $\mathrm{Z}$ & $\mathrm{p}$ \\
\hline Negative Rank & 14 & 8.00 & 42.00 & 2.22 & .07 \\
\hline Positive Rank & 3 & 2.00 & 4.00 & & \\
\hline Equal & 2 & & & & \\
\hline Left Hand & $\mathrm{n}$ & Mean Rank & Sum of Ranks & $\mathrm{Z}$ & $\mathrm{p}$ \\
\hline Negative Rank & 15 & 7.00 & 38.00 & 1.19 & .09 \\
\hline Positive Rank & 2 & 3.00 & 5.00 & & \\
\hline Equal & 2 & & & & \\
\hline
\end{tabular}

It was found that there is no significant difference between the experiment group participants' reaction to light of the right hand and left hand values' pre-test and post-test results ( $>>0.05)$. It was seen that there was an increase in the values of 14 participants, a decrease in the values of 3 participants and no change in the values of 2 participants in the right hand reactions. It was seen that there was an increase in the values of 15 participants, a decrease in the values of 2 participants and no change in the values of 2 participants in the left hand reactions.

Table 2. Comparison of the Control Group's Visual Reaction Pre-test and Post-test Values

\begin{tabular}{|c|c|c|c|c|c|}
\hline Right Hand & $\mathrm{n}$ & Mean Rank & Sum of Ranks & $\mathrm{Z}$ & $\mathrm{p}$ \\
\hline Negative Rank & 13 & 9.00 & 49.00 & 3.17 & .06 \\
\hline Positive Rank & 2 & 3.00 & 4.00 & & \\
\hline Equal & 4 & & & & \\
\hline Left Hand & $\mathrm{n}$ & Mean Rank & Sum of Ranks & $\mathrm{z}$ & $\mathrm{p}$ \\
\hline Negative Rank & 16 & 11.00 & 53.00 & 3.67 & .08 \\
\hline Positive Rank & 1 & 2.00 & 2.00 & & \\
\hline Equal & 2 & & & & \\
\hline
\end{tabular}

It was found that there was no significant difference between the control group participants' reaction to light of the right hand and left hand values' pre-test and post-test results $(p>0.05)$. In the right hand reactions of the control group participants, it was seen that there was an increase in the values of 13 students, a decrease in the values of 2 students and no change in the values of 4 students. It was seen that there was an increase in the values of 16 participants, a decrease in the values of 1 participant and no change in the values of 2 participants in the control group in the left hand reactions.

Table 3. Comparison of the Experiment Group's Auditory Reaction Pre-test and Post-test Values

\begin{tabular}{|c|c|c|c|c|c|}
\hline Right Hand & $\mathrm{n}$ & Mean Rank & Sum of Ranks & $\mathrm{Z}$ & $\mathrm{p}$ \\
\hline Negative Rank & 15 & 5.00 & 27.00 & 3.28 & .09 \\
\hline Positive Rank & 2 & 2.00 & 4.00 & & \\
\hline Equal & 2 & & & & \\
\hline Left Hand & $\mathrm{n}$ & Mean Rank & Sum of Ranks & $\mathrm{z}$ & $\mathrm{p}$ \\
\hline Negative Rank & 16 & 8.00 & 36.00 & 1.56 & .06 \\
\hline Positive Rank & 1 & 4.00 & 7.00 & & \\
\hline Equal & 2 & & & & \\
\hline
\end{tabular}

According to the table 3, it was seen that there was no significant difference between the pre-test and post-test results of the experiment group participants' reaction to sound of the right hand and left hand values $(p>0.05)$. It was determined that there was an increase in the values of 15 participants, a decrease in the values of 2 participants and no change in the values of 2 participants in the right hand reactions in the experiment group. It was determined that there was an increase in the values of 16 participants, a decrease in the values of 1 participant and no change in the values of 2 participants in the left hand reactions in the experiment group. 
Table 4. Comparison of the Control Group's Auditory Reaction Pre-test and Post-test Values

\begin{tabular}{lccccc}
\hline Right Hand El & $\mathrm{n}$ & Mean Rank & Sum of Ranks & $\mathrm{z}$ & $\mathrm{p}$ \\
\hline Negative Rank & 15 & 7.00 & 39.00 & 2.29 & .12 \\
Positive Rank & 2 & 2.00 & 4.00 & & \\
Equal & 2 & & & $\mathrm{z}$ \\
Left Hand & $\mathrm{n}$ & Mean Rank & Sum of Ranks & 3.43 & .24 \\
Negative Rank & 14 & 8.00 & 46.00 & & \\
Positive Rank & 2 & 2.00 & 5.00 & &
\end{tabular}

It was found that there was no significant difference between the pre-test and post-test results of the control group participants' reaction to sound of the right hand and left hand values $(\mathrm{p}>0.05)$.It was seen that there was an increase in the values of 15 participants, a decrease in the values of 2 participants and no change in the values of 2 participants in the right hand reactions of the control group. It was seen that there was an increase in the values of 14 participants, a decrease in the values of 2 participants and no change in the values of 3 participants in the left hand reactions of the control group.

\section{Discussion}

It was determined in our study that the 8 week balance exercises did not create a significant difference in reaction times. When the literature is reviewed, it can be seen that there are studies which show that regular exercises positively affect reaction time (Bompa 1998).

Çankaya et al. (2014), in their study in which they analyzed the effects of special exercises which develop balance in 11 year old male children on reaction times and body mass index, have shown that 8 week special exercise program which develops balance improved the reaction times of athletes and sedentary groups. Arslan (2014) stated that 12 week exercises given to male children aged 8-11 improved their reaction time and that these movements which are required in daily life in terms of life quality will help them do these in purposeful manner and have great contributions on their success in sports. Ölçücü et al. (2010) have given 12 week movement training with balls and without balls to children aged 10-12 who were tennis players $(n=60)$ and have shown that there was significant difference in the sound and light reaction times in the pre-test and post-test values of the group which was given movement training with balls ( $p>0.01$ ). Yildirım et al. (2010), in their study in which they analyzed the effects of physical fitness exercises in youth with intellectual disabilities on reaction times, have determined that there were significant improvements in the reaction times of the experiment group which was given a physical fitness program for 12 weeks according to the results of the pre-test and post-test $(\mathrm{p}<0.05)$. The results indicated that reaction time can be improved with an exercise program in youth with intellectual disabilities.

İri et al. (2017), in their study in which they analyzed the effects of physical activity on the eye-hand coordination and reaction time in children aged 11-14, have determined that although there was no significant difference between the physical activity levels and simple reaction times, male children have a better reaction time compared to female children and that physical activity has effects on reaction time. Can (2007), in his study in which he compared the reaction times of male tennis players, table tennis players and sedentary children in the 10-12 age group, has determined a statistically significant difference between tennis players, table tennis players and sedentary children in terms of reaction time.

As a result, it is indicated in many studies that exercise positively affects reaction time. However, the fact that there is a limited number of studies set with similar parameters which analyzed the effects of balance exercises on reaction time like our study has limited our study. In Çankaya et al. (2014)'s study set in a similar manner, different results were obtained compared to our study. This difference might have resulted due to the fact that female children participated in our study and male children participated in Çankaya et al.'s study, due to the age difference of the groups or that athlete groups were used in their study. According to these results, it is not possible to state the effects of 8 week static balance exercises on reaction time in a definite manner. In new studies to be conducted in this area, implementation of programs consisting of balance exercises along with different exercise protocols for both female and male children together in different age groups might contribute to obtaining healthier results. 


\section{References}

Açıkada, C., \& Ergen, E. (1990). Bilim ve spor, Ankara: Büro-tek ofset Matbaacıllk

Arslan, E. (2014). The effects of the exercise program on visual and audial reaction time of the healty children in the group of 8-11 ages, YYU Journal of Education Faculty, 11(1), 169-182.

Bompa, T. O. (1998). Antrenman kuramı ve yöntemi (Çev: Keskin İ, Tuner B.). Bağırgan Yayınevi. Ankara: 431-441.

Brown, L. E., Ferrigno, V. A., \& Santana, J. C. (Eds.). (2000). Training for speed, agility, and quickness. Champaign, IL: Human Kinetics.

Can, S. (2007). The comparison of reaction time of male tennis players, table tennis players and the ones who don't exercise at all in 10 to 12 age groups. Gazi University unpublished master thesis. Ankara.

Çankaya, S., Gökmen, B., Musa, Ç., \& Taşmektepligil, M. Y. (2014). The effect of special balance developer training applications on reaction time and body mass index of eleven year old young males, Journal of Sports and Performance Researches, 5(2), 59-67.

Çolakoğlu, M., Tiryaki, Ş., \& Moralı, S. (1993). The effect of concentration methods on reaction time, Spor Bilimleri Dergisi, (4) 4, 32-47.

Erdoğan, C. S., Er, F., İpekoğlu, G., Çolakoğlu, T., Zorba, E., \& Çolakoğlu, F. F. (2017). The effects of different type balance exercises on static and dynamic balance performance in volleyball players, Spor ve Performans Araştırmaları Dergisi, 8(1), 11-18.

Eren, E., Müniroğlu, R. S., \& Özer, U. (2017). Examination of visual and auditory reaction times of licensed tennis players in different age groups, International Journal of Cultural and Social Studies (IntJCSS), 3(2), 343-352.

Fox, E. L., Bowers, R. W., \& Fos, L. M. (1999). Beden eğitimi ve sporun fizyolojik temelleri. Ankara: Bağırgan Yayınevi.

Hasdemir, S., Gündüz, N., \& Müniroğlu, S. (2003). The examination of the differences the visual and ouditary reaction times of female handball players at different positions, Spormetre, 1(1), 49-52.

Hazar, F., \& Taşmektepligil, M. Y. (2008). The effects of balance and flexibility on agility in prepuberte period. Spormetre Journal of physical education and Sport sciences, VI(1) 9-12.

İmamoğlu, O., \& Kılcıgil, E. (2007). Türkiye'deki minik futbolcularda reaksiyon zamani, vital kapasite değerleri ve laterizasyon dağiliminda solaklik sorunu, Spormetre, 3(5), 95-100.

İri, R., Aktuğ, Z. B., \& Keskin, A. (2018). The investigation of physical activity on hand-eye coordination and reaction time in children, Spormetre, 16(1), 23-28.

Malina, R. M., \& Bouchard, C. (1999). Growth, maturation, and physical activity. Human Kinetics Publishers İnc, Illinosis.

Muratlı, S. (1997). Çocuk ve Spor-Antrenman Bilimi Işı̆̆̆ Altında, Bağırgan Yayımevi, Ankara.

Ölçücü, B., Cenikli, A., Kaldırımcı, M., \& Bostancı, Ö. (2010). The effects of movement training with and without ball on physical fitness of tennis playing children. Spor ve Performans Araştırmaları Dergisi, 2(1), 32-40.

Sevim Y. (2002). Antrenman Bilgisi. Ankara: Nobel Yayınlar.

Sevimli, D, \& Özoruç, S. (2017). Comparison of Physical Fitness Parameters Among Moderato Level Regular Swimming and Step-Aerobic Exerciser and Sedentary in Females, Turkiye Klinikleri J Sports Sci, 9(1), 40-48.

Yıldırım, N. Ü., Erbahçeci, F., Ergun, N., Pitetti, K. H., \& Beets, M. W. (2010). The effect of physical fitness training on reaction time in youth with intellectual disabilities. Perceptual and Motor Skills, 111(1), 178-186. https://doi.org/10.2466/06.10.11.13.15.25.PMS.111.4.178-186

\section{Copyrights}

Copyright for this article is retained by the author(s), with first publication rights granted to the journal.

This is an open-access article distributed under the terms and conditions of the Creative Commons Attribution license which permits unrestricted use, distribution, and reproduction in any medium, provided the original work is properly cited. 